\title{
コンクリート構造物の長期性能評価 一適用事例と今後の展開一
}

コンクリート構造物の長期性能シミュレーションソフト作成委員会

1.はじめに

日本コンクリート工学会「コンクリート構造物の長期 性能シミュレーションソフト作成委員会」では, これま でにコンクリート構造物の長期性能照査支援ソフトウェア として, 「LECCA (Life Time Evaluation Program for Concrete Structures by Computational Analysis) シリー ズ」と呼ばれる「LECCA 1」,「LECCA 2」,「LECCA 2 Lite」の 3 本を発表しており，それぞれの特徵およびそ の機能の概要については, 既報1,2)に紹介しているとお りである。本稿では, この, 新設のコンクリート構造物 あるいは既設コンクリート構造物の維持管理を想定し, そのための長期性能評価に LECCA シリーズを用いた場 合のケーススタディを紹介する。

また，本シリーズを，より害用性の高いものとするた めに, 現在, 委員会で検討を進めている課題についても, その内容と進渉状況を報告する。

（執筆：野口貴文・山口明伸）

\section{2. 塩害を対象としたケーススタディ}

既設コンクリート構造物の維持管理においては, まず 劣化機構を推定し, 劣化予測に基づいて, 構造物のライ フサイクルを通して要求性能を満足させることが必要と なる。ここでは, 塩害環境下にある構造物の維持管理を 想定し, ひび割れからの局所的な劣化進行の影響, 各種 補修方法を比較して適切な補修方法と実施時期の選択 (以下, 補修計画), 調查結果を用いた劣化予測と補修計 画，の3つのケースについてケーススタデイを行った。

\section{1 初期ひび割れを有する構造物の補修計画}

解析の条件を表-1 に示す。初期からひび割れが発生 している状況を想定しているため, ひび割れによるマク ロセル腐食の影響を考慮できるようにLECCA 2 を用い て検討した。供用 5 年後の塩分浸透状況と腐食量分布を 図-1 に示す。今回の条件では, 初期ひび割れは鉄筋位置 まで到達していないが，ひび割れ位置では塩分が浸透し やすいため, マクロセル腐食に伴い 5 年後には $2 \mathrm{mg} / \mathrm{cm}^{2}$ 程度腐食していることがわかる。
表-1 解析条件 (塩害)

\begin{tabular}{|c|c|}
\hline 気 & 東京 標準年 \\
\hline 配 & OPC, $W / C=50 \%, C=340 \mathrm{~kg} / \mathrm{m}^{3}$, 空隙率 $=0.2$ \\
\hline 形 & $\begin{array}{l}\text { かぶり }=75 \mathrm{~mm}, \text { 鉄筋径 }=20 \mathrm{~mm} \\
\text { ひび割れれ: 離散型, 間隔 }=500 \mathrm{~mm}, \text { 深さ }=50 \mathrm{~mm}, \\
\text { 幅 }=0.1 \mathrm{~mm}\end{array}$ \\
\hline 塩分浸透 & $\begin{array}{l}\text { 初期塩分 }=0 \mathrm{~kg} / \mathrm{m}^{3}, \text { 海洋 : 表面塩分量 }=13 \mathrm{~kg} / \mathrm{m}^{3}, \\
\text { 見掛けの拡散倸数 }=1.334 \mathrm{~cm}^{2} / \mathrm{y}\end{array}$ \\
\hline 鉄筋腐食 & 腐食発生塩分量 $=1.2 \mathrm{~kg} / \mathrm{m}^{3}$, 腐食速度 : 宮里モデル \\
\hline
\end{tabular}

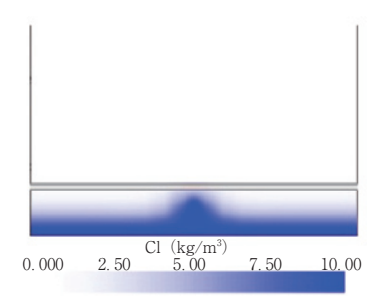

図-1 5 年後の塩分浸透

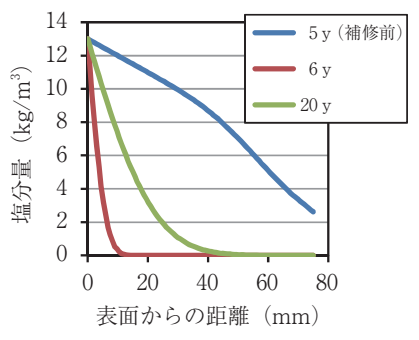

ひび割れから $15 \mathrm{~mm}$ の位置

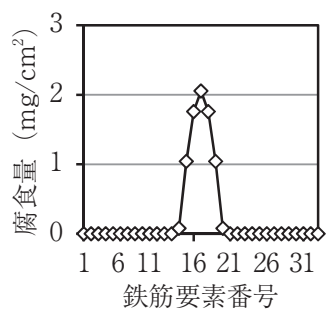

（左）と腐食量分布（右）

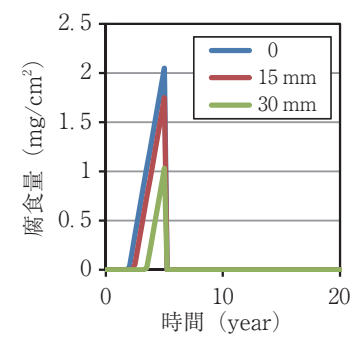

ひび割れからの距離による違い
図-2 断面修復後の塩分浸透（左）と腐食量分布（右）

このような劣化状況では, 鉄筋背面まで母材コンク リートをはつりとり，断面修復工法を適用することが一 般的である。供用 5 年後にこのような補修を実施した結 果を図-2に示す。適切な補修を実施すれば，補修後の 劣化進行を抑制することができることがわかる。

最近では補修後の再劣化の検討も進み, 再劣化防止を 踏まえた補修が実施されるようになり始めたが，過去には， 不適切な補修によって, 補修後わずか数年で再劣化が生じ るなどの事例があった。例えば，前述のケースと同じ断面 修復工法を適用する際でも，母材コンクリートのはつり深 さとして,ひび割れは超えるものの鉄筋の手前までの断面 


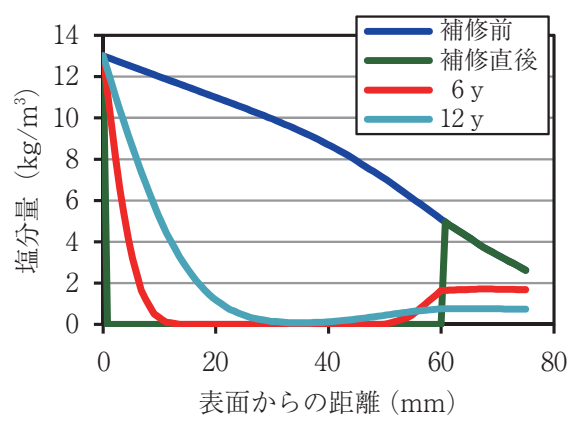

図-3 ひび割れから $15 \mathrm{~mm}$ 位置の塩分状況

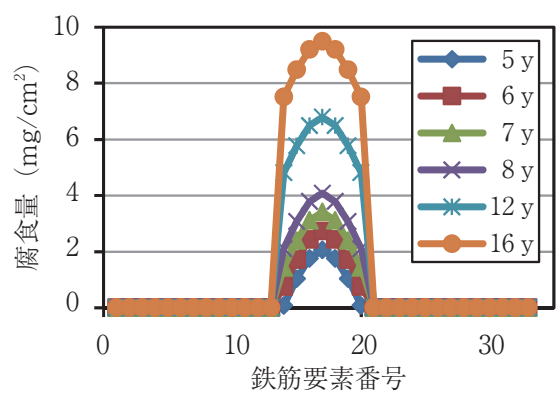

図-4 腐食量分布の経時変化
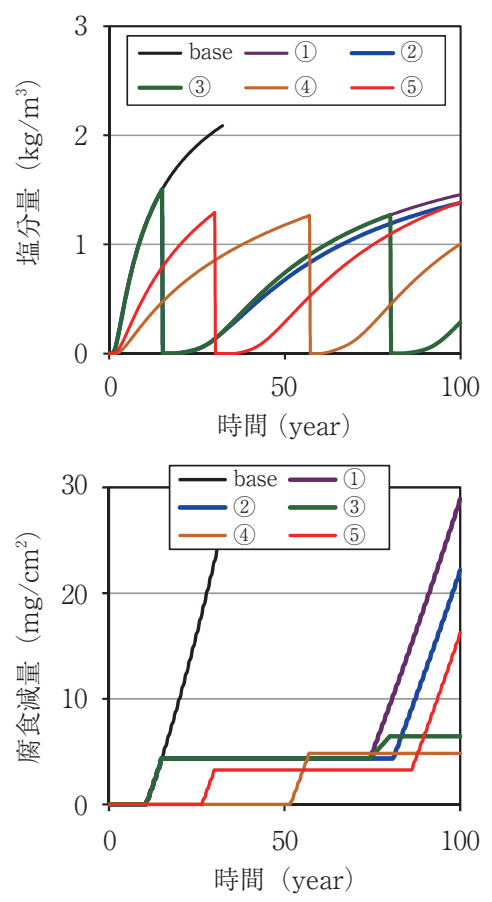

図-5＼cjkstart各種補修工法を用いた塩分浸透と腐食減量

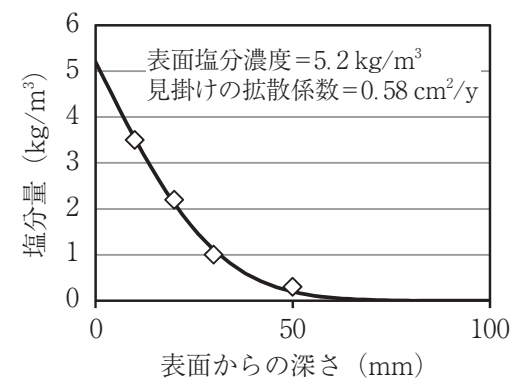

図-6 5 年後の調査結果と逆推定結果
（60 mm）を補修対象としている場合などである。そのよ うな補修を施した場合の塩分浸透状況を図-3に示すが, $60 \mathrm{~mm}$ 以深の塩分が除去できておらず，残った塩分が補 修後に再拡散する状況が予測されている。このような補修 では，鉄筋位置に塩分が存在しているため，図-4に示す ように腐食の進行を全く抑制していない。このように補修 範囲を比較した評価を実施することで，塩分が既に浸透し ている鉄筋背面まではつりとることの重要性が明確となる。

\section{2 各種補修工法の比較}

補修工法の比較のため, コンクリートのモデル化が簡易 な LECCA 2 Liteを用いて検討した。海岸から $100 \mathrm{~m}$ の 位置に存在する陸上構造物を対象とし，かぶりは $50 \mathrm{~mm}$ と設定している。比較した補修工法は次のとおりである。

(1)断面修復 + 表面被覆を 15 年目に実施

(2)断面修復＋表面被覆を 15 年目に実施し，その後 10 年ごとに表面被覆を更新

(3)断面修復 + 表面被覆を 15 年目と 80 年目で実施

(4)表面含浸材 A を建設時に適用し, 断面修復+表面 被覆を 57 年目に実施

(5)表面含浸材 B を建設時に適用し，断面修復＋表面 被覆を 30 年目に実施

図-5に鉄筋位置における塩分浸透状況と腐食減量の 経時変化を示す。なお，断面修復した場合は鉄筋の腐食 部分を除去するため, 図-2に示したように腐食量とし てはゼロにリセットされるが，ここでは，鉄筋の初期状 態からの腐食減量（鉄筋の断面減少量）として表示して いるため，ゼロにリセットされていないことに注意され たい。この結果から，表面含浸材の種類や，断面修復お よび表面被覆の更新の影響などを，ケーススタディの結 果から理解することができる。今回のケーススタディで は，(4)の補修工法を選択した場合に最も腐食減量が少な く，初期に表面含浸材 A を適用することで塩分浸透が 抑制されて腐食発生時期が遅れ，さらに57 年目に断面 修復と表面被覆を施すことで，その後の腐食発生を抑制 できると評価されている。実際の補修工法の選定におい ては，これらの情報に加えてライフサイクルコストを用 いて，適切な工法を選択することが重要となる。

\section{3 調査結果を用いた劣化予測と表面被覆工法の影響}

塩害の最後のケーススタディは, 供用 5 年後に塩分濃 度分布を測定した結果から，表面塩分濃度と見掛けの拡 散係数を算出し，これらの数值を用いてその後の劣化予 測と表面被覆工法の効果について検討した例である。な お，かぶりは $75 \mathrm{~mm}$ としている。図-6に 5 年後の塩分浸 透状況の調査結果（前提として仮定したもの）とそれに 対するフィックの拡散方程式のフィッティングによる逆推 定結果を示す。調査の結果， 5 年目では鉄筋位置までは塩 分が浸透していなかったことから，断面補修は行わずに 供用 10 年目に表面被覆工法を施すことで対処したとする。 その場合の補修効果を, 耐用年数 10 年の表面被覆 $\mathrm{A}$ を 

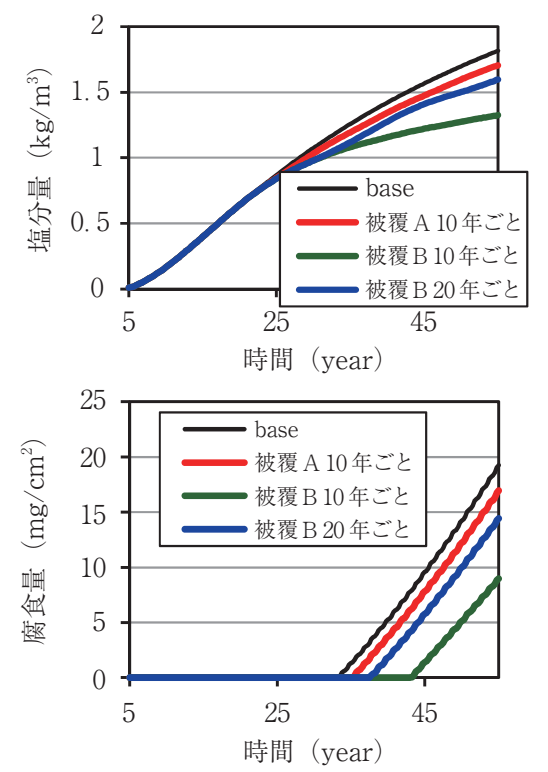

図-7 塩分浸透状況と腐食量

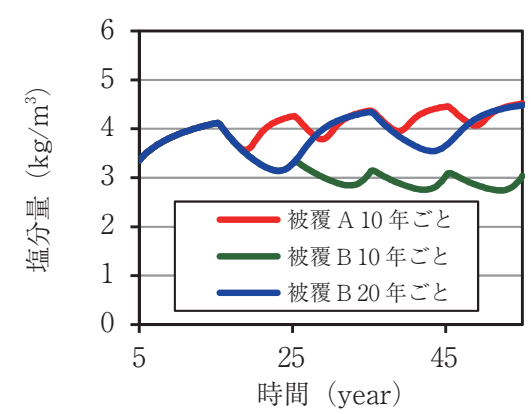

図-8 表面から $11.18 \mathrm{~mm}$ における塩分浸透状況

10 年ごとに更新する場合と, 耐用年数 20 年の表面被覆 B を 10 年ごとおよび 20 年ごとに更新する場合で比較した。

図-7に鉄筋位置における塩分浸透状況と腐食量の経 時変化を示す。前述のように，塩分が残存した状態で表 面被覆のみを適用した場合の比較であるが，耐用年数 20 年の表面被覆 B を 10 年ごとに更新することで，ある 程度，腐食を抑制できていることがわかる。図-8に表 面から $11.18 \mathrm{~mm}$ における塩分濃度の経時変化を示すが, 表面被覆の経年劣化に伴い，外部からの塩分浸透を抑制 できていない場合（塩分濃度が増加傾向）と，抑制でき ている場合（塩分濃度が減少傾向）があり，抑制効果が 周期的に変動している。このように，補修材料の耐久性 や経年劣化の特性を導入することで，長期的な補修効果 をより詳細に評価し, 環境外力と劣化状況に応じた最適 な補修工法と補修材料を選定することが可能となる。

(執筆：加藤佳孝)

3.中性化を対象としたケーススタディ

コンクリートの中性化は，主として気中の二酸化炭素 に起因して生じるため, 構造物の置かれる一般的な環境 において等しく考慮すべき劣化現象の一つである。特に 建築物の一般環境下における耐久性は，主として中性化
表-2 解析条件 (新規建築物 中性化)

\begin{tabular}{|c|c|}
\hline 気 & 東京 標準年 \\
\hline 環境条件 & 屋外, 雨がかりなし \\
\hline 配 & OPC $, \quad W / C=60 \%, \quad W=170 \mathrm{~kg} / \mathrm{m}^{3}, \quad C=283 \mathrm{~kg} / \mathrm{m}^{3}$ \\
\hline 仕 & かぶり $=30 \mathrm{~mm}$, 鉄筋径 $=13 \mathrm{~mm}$ \\
\hline 状 & ひび割れ：なし \\
\hline 鉄筋腐食 & 腐食発生条件：中性化残り $0 \mathrm{~mm}$ \\
\hline \multirow[t]{4}{*}{ 仕上材料 } & $\begin{array}{l}\text { 有機系表面被覆材：薄塗材 } \mathrm{E} \\
\text { 耐用年数 }: 5 \text { 年, 膜厚 }: 1000(\mu \mathrm{m}) \text {, 透過係数 }: 2.00 \times \\
10^{-7} \mathrm{~cm}^{3}(\mathrm{STP}) \cdot \mathrm{cm} /\left(\mathrm{cm}^{2} \cdot \mathrm{sec} \cdot \mathrm{cmHg}\right)\end{array}$ \\
\hline & $\begin{array}{l}\text { 有機系表面被覆材：複層塗材 } \mathrm{E} \\
\text { 耐用年数 } 15 \text { 年, 膜厚 }: 2000(\mu \mathrm{m}), \text { 透過倸数 }: 0.10 \times \\
10^{-7} \mathrm{~cm}^{3}(\mathrm{STP}) \cdot \mathrm{cm} /\left(\mathrm{cm}^{2} \cdot \mathrm{sec} \cdot \mathrm{cmHg}\right)\end{array}$ \\
\hline & $\begin{array}{l}\text { モルタル：反応定数 : } 5000000 \text { (1/day), } \mathrm{Ca}(\mathrm{OH})_{2} \text { 量 } \\
0.001\left(\mathrm{~mol} / \mathrm{cm}^{3}\right) \text {, 空隙率 }: 0.1\end{array}$ \\
\hline & $\begin{array}{l}\text { ポリマーセメントモルタル：反応定数： } 5000000(1 / \text { day), } \\
\mathrm{Ca}(\mathrm{OH})_{2} \text { 量 }: 0.001\left(\mathrm{~mol} / \mathrm{cm}^{3}\right) \text {, 空隙率 }: 0.05\end{array}$ \\
\hline
\end{tabular}

を念頭に検証されている。

中性化の進行した既存構造物においては，仕上材の維 持保全による性能確保が検討されることが一般的である が, 近年では, さらなる長寿命化への要求により，新規 物件においてもあらかじめ仕上材を施して長期的な性能 を確保する手法がとられることも少なくない。

ここでは，これらのケースを想定し，仕上材の更新周 期や補修方法などを主な水準として LECCA 2 あるいは LECCA 2 Lite を用いて検討する。

本節で用いた，建築物の基本仕様および設定した仕上 材料，補修材料の物性を表-2 に示す。

なお, 有機系表面被覆材の耐用年数設定においてはピ ンホールや局所的な破損・劣化は想定していない点，モ ルタル仕上げなどについても浮き・ひび割れ等の局所的 な破損・劣化が生じていないことを前提としている点に 注意が必要である。

\section{1 新設構造物の補修計画}

鉄筋コンクリート造建築物を想定し，新設構造物の補 修計画について検討した。

鉄筋コンクリート造建築物の多くは，コンクリート表面 に，建築用仕上塗材や塗装，夕イルなどの仕上げが施され るのが一般的である。しかしながら，これら仕上材料の躯 体保護効果を考慮する場合には，どの程度の頻度で仕上 材の更新をすれば十分な効果を得ることができるかが問題 となる。通常，建築用の仕上材の多くは，耐用年数は 5 年 から 15 年と言われているが, これら仕上材の補修（更新） は，単に躯体保護性能の観点のみで行われているわけでは なく, むしろ, 色調や光沢度, 割れや, チョーキングといっ た意匠的な観点も含めた総合的工学判断のもと更新される のが一般的である。したがって，必ずしも躯体保護性能の 観点から適切な仕上材の更新がなされるわけではない。

そこで，本項ではまず新築時に導入される仕上材の効 果について，一般的な仕様の建築物（W/C 60\%，かぶ り厚さ $30 \mathrm{~mm}$ ）を想定し，主として仕上材の更新間隔 


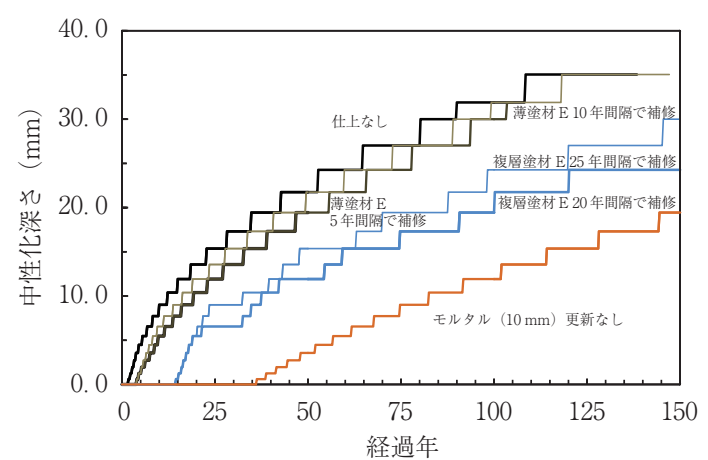

図-9 耐用年数で仕上材を更新した場合の中性化予測

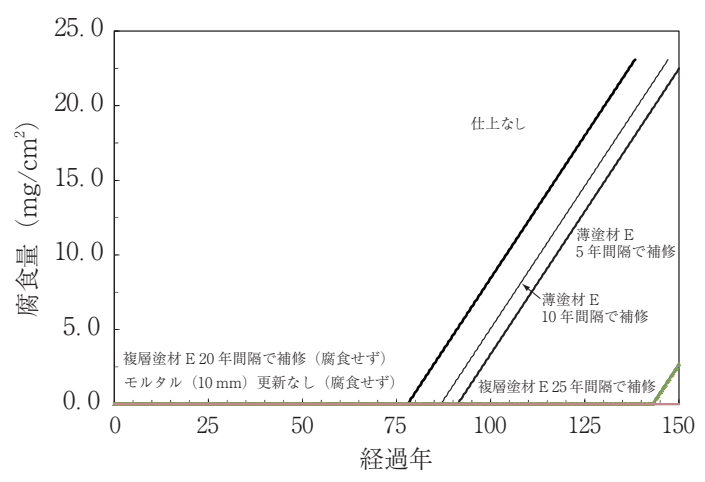

図-10 耐用年数で仕上材を更新した場合の腐食量

の観点から検討を行った。検討結果を図-9, 図-10に示 す。仕上なしの場合， 70 年近く経過した時点で鉄筋腐 食が開始している。

これに対して，建築物で一般的に使用されている薄塗 材 $\mathrm{E}$ ，複層塗材 $\mathrm{E}$ を想定した有機系仕上材を表-2 のと おり設定し，これを用いた維持保全についてケースス夕 デイを行った。

薄塗材 $\mathrm{E}$ の場合, 耐用年数とした 5 年間隔で更新し た場合であっても，90 年程度で腐食が発生しており， たとえ適切にメンテナンスしたとしてもその効果は限定 的である。実際には，薄塗材 $\mathrm{E}$ の更新間隔が 5 年を超 えることも少なくないが，更新周期を 10 年とした場合， さらにその効果はほとんど期待されない程度となった。

これに対し，複層塗材は塗厚が大きく，トップコートは 痛むものの, 中塗材の耐用年数は長く, 躯体保護性能は 20 年と設定した。 20 年の更新周期で設定した場合， 150 年の供用期間中は腐食が発生しない結果となった。通常, 複層塗材はトップコートの更新を 10 年から 15 年程度で 行うことが一般的であり，複層塗材の塗布により供用期間 中の腐食を予防できることが示唆される。これに対して， あまり現実的ではないものの，これを 25 年の更新周期と した場合，140 年を超えた時期に腐食発生が予測された。 このように，更新周期によって，その躯体保護効果に差が 生じる点をより定量的に評価できることが示された。

また，参考として図中にモルタル仕上げ（10 mm）を 施した場合の解析結果も示しており，モルタル仕上げに より十分な耐久性が確保できることがわかる。これは，
表-3 解析条件（既存建築物 中性化）

\begin{tabular}{|c|c|}
\hline 気 & 東京 標準年 \\
\hline 築 年 数 & 築 40 年 \\
\hline 環境条件 & 屋外, 雨がかりなし \\
\hline 劣化状況 & $\begin{array}{l}\text { 中性化深さ } 20 \mathrm{~mm} \\
\text { 耐久性上有害なひび割れ等は確認されていない }\end{array}$ \\
\hline 仕 様 & $\begin{array}{l}\text { かぶり }=30 \mathrm{~mm}, \text { 鉄筋径 }=13 \mathrm{~mm} \\
\text { 調査時点では仕上なし (打ち放し) }\end{array}$ \\
\hline 各種物性 & $\begin{array}{l}\text { 二酸化炭素拡散係数：20.5 }\left(\mathrm{cm}^{2} / \text { day }\right) \\
\text { 空隙率 : } 0.292 \quad * \text { LECCA の逆解析機能を利用 }\end{array}$ \\
\hline 補修材料 & 表-2 に同じ \\
\hline
\end{tabular}

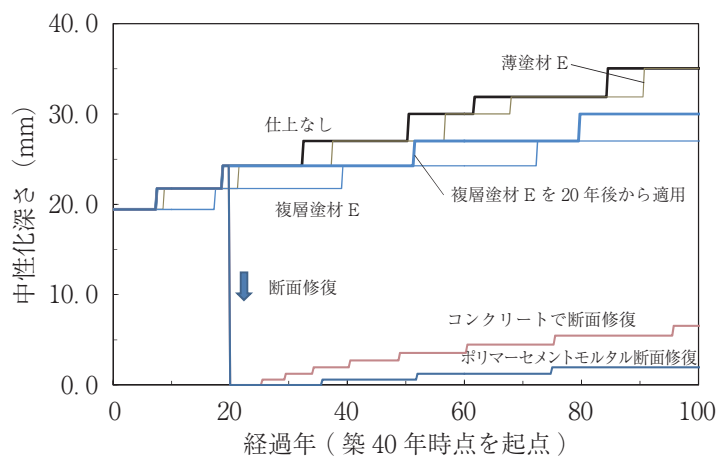

図-11 既存構造物に仕上材・補修材を適用した場合の中性化予測

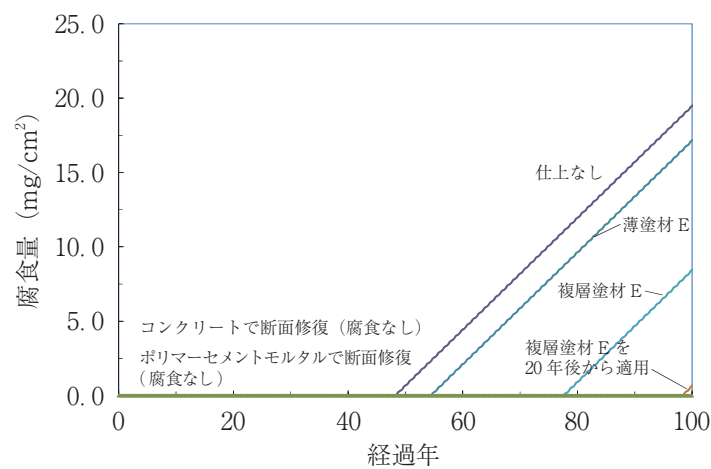

図-12 既存構造物に仕上材・補修材を適用した場合の腐食量

マンションなどで一般的に用いられるタイル仕上げの場 合も同様で，タイルの躯体保護効果を考慮しないでも， 下地モルタルのみでも一定の躯体保護効果が得られるこ とを示唆するものである。

今後，これら性能をより正確に記述することで，更新 周期との関係から，どの程度躯体保護性能を有するかを より正確に見積もることができることが期待される。

\section{2 既存構造物のメンテナンス計画への適用}

既に劣化が進行した既存建築物は，仕上材の適用を主 軸とした維持保全計画が立てられることが多い。

そこで，表-3に示すように劣化が進行した既存構造 物を想定し，その後の補修計画について検討を行った。

試算結果を図-11, 図-12 に示す。調査時点で仕上の施 されていないこの建築物は, このままの状態で劣化が進行 すると，あと 50 年ほどで鉄筋腐食が開始する。これに対 
して，仕上材を施した場合，薄塗材ではほとんどその効果 を期待できないが, 複層塗材を塗布して適切にメンテナン スすればあと 100 年程度腐食を抑えることが可能である。

これに対して，あと 20 年メンテナンスせずに放置し た場合，複層塗材を塗布しても 60 年を超えたところで 鉄筋腐食が進行し始めることが予測される。この場合, コンクリートやポリマーセメントモルタルによる断面修 復の適用を 20 年後に行っても, 鉄筋腐食の発生を抑え られる結果となっている。

このように，既存構造物の延命に，仕上材の適用や各 種補修がどのような影響があるかを，詳細な中性化解析 により検討することが可能である。

（執筆：兼松 学・宮里心一）

\section{4. 今後の展開}

\section{1 部材・部位ごとの環境外力評価}

LECCA シリーズでは，コンクリート構造物の外部環 境として, マクロ環境（構造物が建設される地域を包括 する気象条件), メゾ環境（構造物の部位・部材周辺の 環境条件), ミクロ環境（外部環境とコンクリートと境 界）の3つに区分している。しかし，現行モデルでは， メゾからミクロ環境へのデータの受け渡しを部材・部位 ごとに評価するまでには至っていない。そこで本委員会 では，飛来塩分による塩害環境に扔いて，粒子拡散手法 の一種であるランダムウォーク法 $(\mathrm{RW} \text { 法 })^{3)}$ により部材 · 部位ごとの表面付着塩分量の評価法に関する検討を行っ ている。 RW 法では, 飛来塩分を異なる塩分濃度を持っ た多数の粒子で表現し，風速場に応じた粒子の移流・拡 散を計算することができる。また，構造物への粒子の付 着も容易に表現可能な手法である。図-13にRW 法の解 析手順を示す。 RW 法の解析を大きく分けると(1)有限要 素法による風速場の解析, (2)有限要素法から得られた風 速場を利用した粒子の移流・拡散（粒子は風速に依存し た拡散性状を有する) ・付着解析の二段階からなる。

RW 法を LECCA シリーズに導入する際は, メゾ環境 のモデルである宇多モデルから得られる飛来塩分の空間 的濃度分布等を境界条件として飛来塩分粒子の移流・拡 散・付着を解くことを予定している。また，RW 法から 得られた部材・部位ごとの付着塩分量を用いてミクロ環 境モデル4) に用いる飛来塩化物イオン量を決定すること ができれば，ミクロ環境モデルの部材・部位ごとの評価 が可能となる。図-14に宇多モデルと RW 法が対象とし ている領域の模式図を示す。

次に本委員会で検討している解析ケースを簡単に紹介 する。対象構造物は，図-15に示す断面形状を有する橋 梁上部工で下フランジがない断面に加え，下フランジが ある断面についても検討を行っている。検討ケースを 表-4に示す。

ここでは, 検討ケースのうち 5 連桁の＃20風速を 3

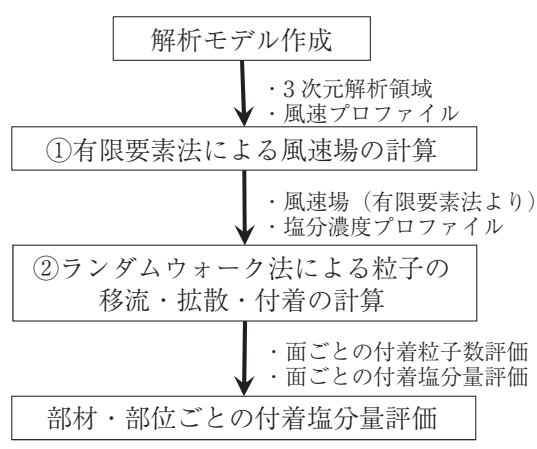

図-13 解析フロー

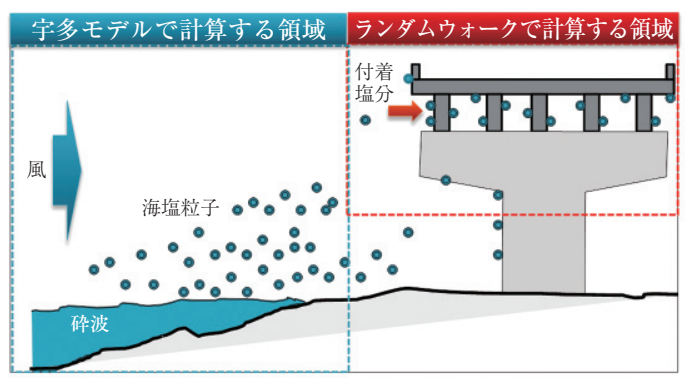

図-14 計算対象模式図

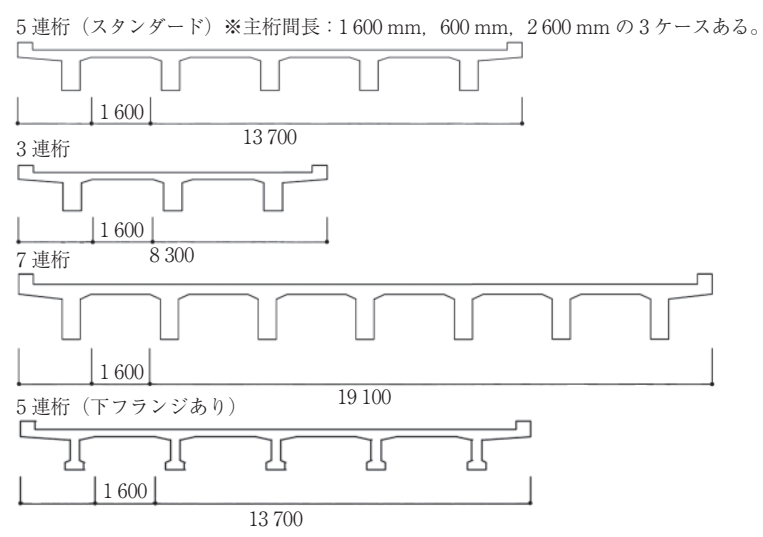

図-15 解析対象上部工断面（検討モデル）

表-4 検討ケース

\begin{tabular}{|c|c|c|c|c|}
\hline 解析ケース & 主桁数 & 主桁間長 $(\mathrm{mm})$ & 風速 $(\mathrm{m} / \mathrm{s})$ & 下フランジ \\
\hline$\# 1$ & \multirow{3}{*}{5} & 600 & \multirow{3}{*}{$1,3,5$} & \multirow{3}{*}{ 無 } \\
\hline$\# 2$ & & 1600 & & \\
\hline$\# 3$ & & 2600 & & \\
\hline$\# 4$ & \multirow{3}{*}{3} & 600 & \multirow{3}{*}{$1,3,5$} & \multirow{3}{*}{ 無 } \\
\hline$\# 5$ & & 1600 & & \\
\hline$\# 6$ & & 2600 & & \\
\hline$\# 7$ & \multirow{3}{*}{7} & 600 & \multirow{3}{*}{$1,3,5$} & \multirow{3}{*}{ 無 } \\
\hline$\# 8$ & & 1600 & & \\
\hline$\# 9$ & & 2600 & & \\
\hline \# 10 & 5 & 1600 & 3 & 有 \\
\hline
\end{tabular}

パターン変えた場合の付着塩分量の違いと＃10の下フラ ンジが付着塩分量に与える影響を検証した結果を示す。

図-16に\#2（風速 $3 \mathrm{~m} / \mathrm{s}$ ）の風速ベクトル図を示す。 この図より, 主桁間に生じた大きな渦により, 飛来塩分 が巻き上げられることが予想される。また，図-17に飛 
来塩分粒子の移流・拡散・付着の結果を示す。両図を比 較することにより, 粒子が濃度拡散と風速場に応じた移 流によって主桁間にも巻き上げられ, 主桁の内側や床版 にも付着している様子が確認できる。

図-18, 図-19に＃2 と＃10の部材面ごとの単位面積当 たりの付着塩分量評価を示す。図-18に示した下フランジ なしの風速場の違いによる付着粒子数評価からは, 主桁 下面に塩分粒子が多く付着する傾向にあり，また，風上

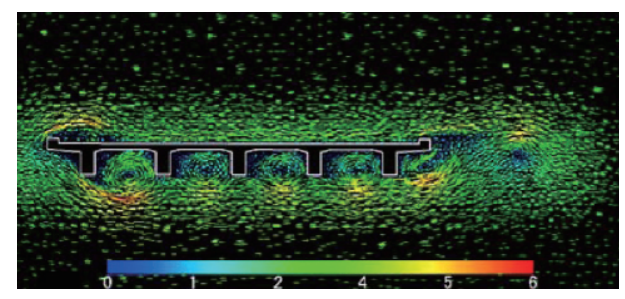

図-16 風速ベクトル（3 次元有限要素法）

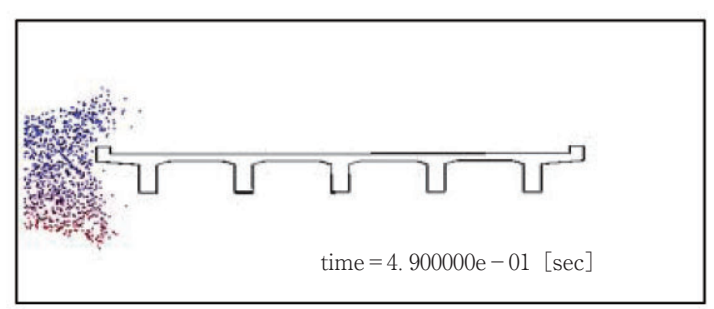

(a) 0.5 秒後

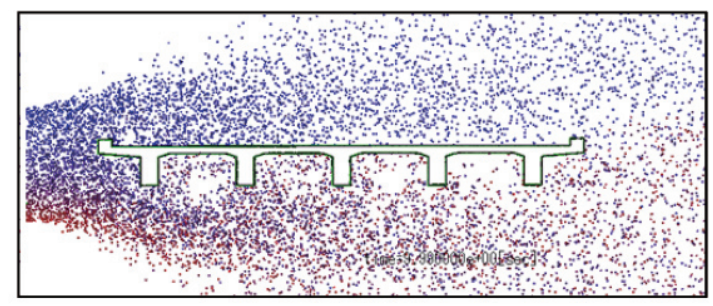

(b) 10 秒後

図-17 飛来塩分シミュレーション（RW 法）

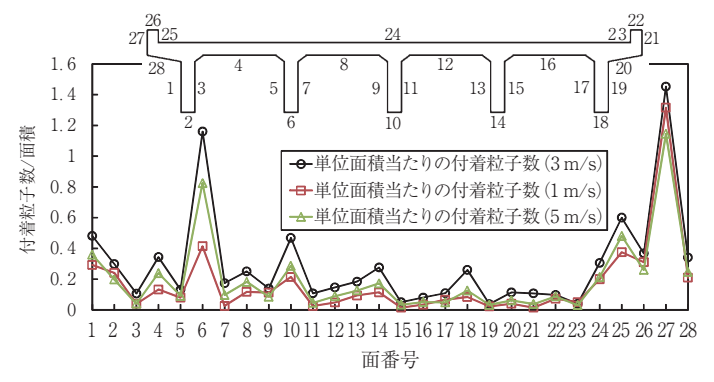

図-18 面ごとの付着塩分量評価（， 2)

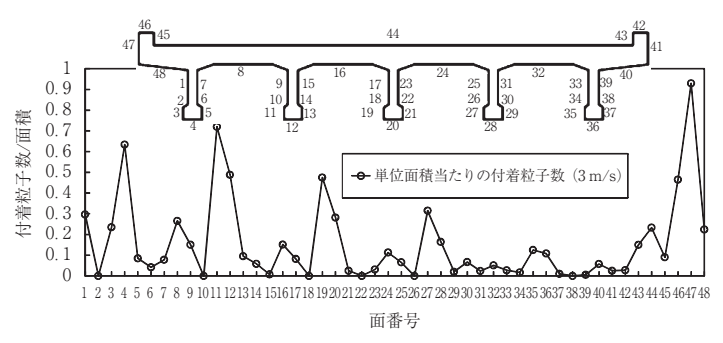

図-19 面ごとの付着塩分量評価（＃ 10）
（海側）から 2 番目の主桁下面に付着する傾向にあること がわかる。図-19に示した下フランジありの場合は, なし の場合と同様に風上（海側）から 2 番目の主桁に多く付 着する傾向にあるが，下フランジなしと異なり下面よりも 下フランジ側面（海側）に多く付着する傾向を示した。

以上のように RW 法は, 構造物の部材・部位ごとに 付着塩分量の評価を簡単に行うことができ，さらに拡散 モデルや付着モデルなどの設定を柔軟に行える。

このように, RW 法は, 飛来塩分などのエアロゾルの拡 散挙動の計算ツールとして有用であり, 今後の LECCA シリーズに導入され外部環境評価に活用されることが期 待されている。

（執筆：富山 潤）

\section{2 構造性能評価}

コンクリート構造物の合理的な維持・管理を行うため に, 既設構造物が保有する力学性能（構造性能）の評価 や構造物の長期的な劣化予測などを可能にする長期性能 評価手法の開発と利用が期待されている。現状の LECCA 2 は, 構造物の力学性能を予測する構造解析手 法との統合はなされておらず, また構造物の全体的な劣 化情報を提供するには至っていない。したがって, LECCA 2 が出力する局部的な劣化情報に基づいて, 構 造物または部材の構造性能をいかに評価するかが課題と なっている。

\section{（1） LECCA 2 が出力する情報}

LECCA 2 が対象とする領域は，部材の側面部と隅角 部の 2 種類の 2 次元形状であり, 解析範囲は最大で $500 \mathrm{~mm}$ となる。鉄筋は, 連続した 1 本がモデル化され, 長さ $15 \mathrm{~mm}$ の鉄筋要素の集合として扱われる。また, 側面部の解析ではひび割れを扱うことができ，解析対象 の表面にひび割れが一様に存在しているとする「分散型」 と，ひび割れ 1 本を扱う「離散型」の 2 種類のモデル化 が可能である（図-20）。

LECCA 2 により, 断面内の塩化物イオン濃度の分布 や中性化深さなどの情報を得ることができるが，構造性

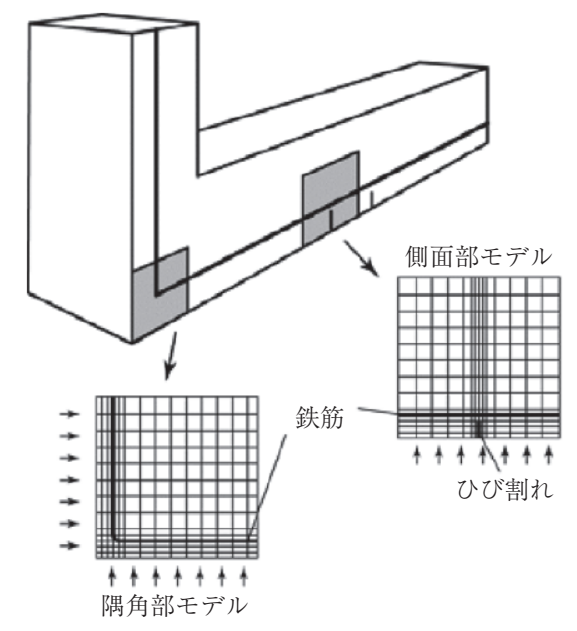

図-20 解析対象のモデル化 


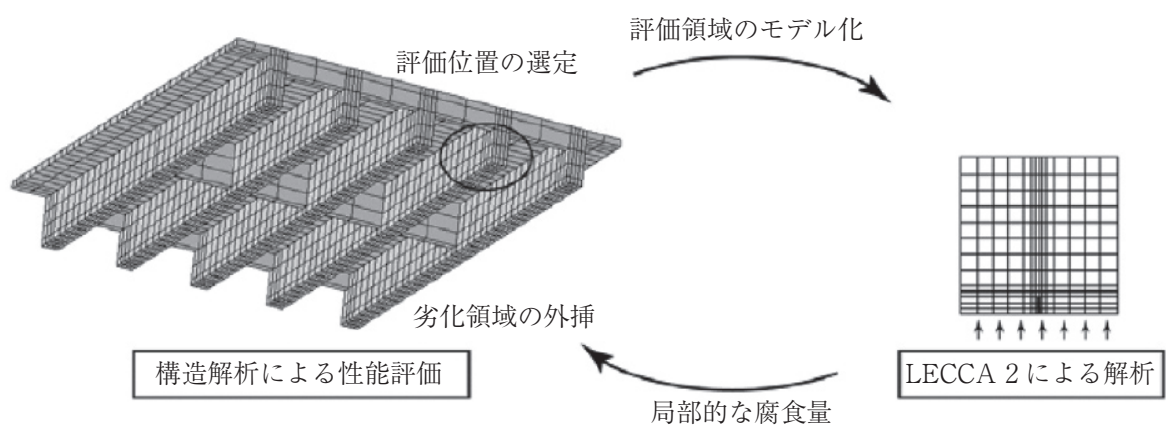

図-21 LECCA 2 を用いた構造性能評価の流れ

能評価に用いる情報は, 直接的には鉄筋の腐食量（ひび 割れを有する場合は腐食量分布）となる。つまり， LECCA 2 より出力される局部的な鉄筋の腐食量を用い て, 構造物または部材の全体的な鉄筋腐食分布を外挿し, 構造性能の評価を行うことになる。

（2）構造物または部材の評価

図-21に，LECCA 2 を用いた構造物の構造性能評価 の流れを示す。有限要素法に代表される構造解析手法に より，鉄筋腐食の生じた鉄筋コンクリート部材の耐荷性 状を評価するには，鉄筋の腐食量をインプットとし，鉄 筋の断面減少や付着劣化の影響を考慮した材料モデルを 適用することになる5)。このとき部材の耐荷力や変形性 能は，鉄筋の腐食分布（腐食のばらつき）の影響を大き く受けることが既往の研究より明らかとなっている6 しかしながら，危険断面に対して鉄筋の腐食量の最大值 を想定すれば，部材の最小の耐荷力を㧍扮むね評価でき るものと考えられるので, LECCA 2 では危険断面の局 部的な腐食状況を想定してやればよい。

(3) 構造性能評価の可能性

LECCA 2 は, 解析対象が 2 次元かつ局部的であり， 複雑な断面形状や配筋なども考慮することができない。 したがって，LECCA 2 を用いた構造性能評価では，対 象とする構造物または部材において評価位置を適切に設 定するとともに，その評価範囲をLECCA 2 の解析モデ ルに上手く簡略化して落とし込まなければならない。さ らに, LECCA 2 より得られる局部的な情報は, 構造物 または部材の劣化情報に適切に反映させる必要がある。 このように，現状では LECCA 2 を構造性能評価に用い るにはかなりの制約があるが，適切に利用すれば効果的 な維持・管理に参考となる有用な情報を得ることは可能 である。今後, LECCA 2 の 3 次元化やより複雑なモデ ル化が可能となれば，その適用方法も更に広がるものと 期待される。将来的には, 環境外力の評価から, 材料劣 化の予測，そして構造性能の評価までをシームレスに実 行できる長期性能評価手法が開発されれば，構造解析技 術に基づいた適切な点検個所や方法の選定，定量的な構 造性能の評価, 効果的な補修・補強方法の選定を行うこ とが可能となるであろゔ?

(執筆：斉藤成彦)

\section{5.おわりに}

本稿では，日本コンクリート工学会「コンクリート構 造物の長期性能シミュレーションソフト作成委員会」で 開発した「LECCA シリーズ」を用いたケーススタディの 紹介と今後の展開についての報告を行った。ケースス夕 ディでは，塩害および中性化に対するコンクリート構造 物の長期性能評価を具体的な事例を想定して実施し，本 ソフトが構造物の維持管理計画策定のための支援ツール として活用可能であることを示した。ただし，その際には， 対象構造物に関するデー夕だけでなく，選択肢となる補 修材料の物性や特性に関する情報を事前に十分に収集・ 把握しておくことが前提となることを再度付記しておく。

また，後半には，現在取り組んでいる課題である，環境 外力のより詳細な評価手法や, 構造性能の評価手法につい てその検討状況を紹介した。環境条件，材料条件，形状． 構造の異なる種々のコンクリート構造物に対して, 単独あ るいは複合的な劣化現象の長期的進行を正確に予測するこ とは，依然困難であるが，不確かな劣化予測に基づいて立 案せざるを得ない現状の維持管理計画策定において，実験 あるいは理論に基づいて構築された LECCA シリーズをそ の支援ソフトとして有効に活用いただければ幸いである。

(執筆：山口明伸)

\section{参考文献}

1）コンクリート構造物の長期性能シミュレーションソフト作成委員 会：コンクリート構造物の長期性能評価一環境外力の評価手法一, コンクリート工学, Vol.50, No.10, pp.946〜950, 2012. 10

2）コンクリート構造物の長期性能シミュレーションソフト作成委員 会：コンクリート構造物の長期性能評価一材料劣化の予測モデル—, コンクリート工学, Vol.50, No.11, pp.1057〜1063, 2012. 11

3）例えば，田中孝和・富山 潤・伊良波繁雄・吉村 忍：ランダム ウォーク法による飛来塩分の拡散シミュレーションに関する研究, コ ンクリート工学年次論文報告集, Vol.26, No.1, pp.789〜 794, 2004

4）山田義智・大城 武・桝田佳寛：塩害環境下におけるコンクリー ト中への塩化物イオンの浸透に関する解析的研究, 日本建築学会 構造系論文集, No.501, pp.13〜18, 1997. 11

5）李 翰承・野口貴文・友澤史紀：引張鉄筋の腐食した RC 梁の有 限要素法による耐力性能評価に関する基礎的研究, 日本建築学会 構造系論文集, No.506, pp.43〜 50, 1998

6）斉藤成彦・高橋良輔・檜貝 勇 : 鉄筋の腐食分布が $\mathrm{RC}$ はり部材 の曲げ耐荷性状に及ぼす影響, 土木学会論文集 E, Vol.64, No.4, pp.601 611, 2008

7）土木学会：続・材料劣化の生じたコンクリート構造物の構造性能 評価, コンクリート技術シリーズ 85, 2009 